\title{
TIYATRO BILIMi
}

\section{Prof. Dr. MELÂHAT ÖZGÜ}

Ưlkemizin henüz bütün il ve ilçelerinde değilse bile, büyük kentlerimizde artık bir tiyatro yaşamından söz edebiliyoruz: Tiyatrolarımız çoğaldı; Dünya tiyatrolarında oynanan oyunların dilimize çevirileri arttı, yerli oyunlarımız tutundu, seyircilerimiz yetişti. Bütün bunları tarihsel gelişimi içinde araştırıp, kurumları, deneysel öğeleriyle inceleyerek, yorumlayarak, yabancı milletlerdekilerle karşılaştırarak değerlendirmenin, kültür alanında tiyatronun oynadığı büyük rolü düşünerek varlığımızı bilinçli olarak göstermenin zamanı geldi. Bu kaygı ile, Ankara Üniversitesi, Dil ve Tarih-Coğrafya Fakültesi, bütün üniversitelerimize öncülük ederek, 1964 yılında bir Tiyatro Kürsüsü kurmuş ve tiyatroyu, üniversite kürsülerinin öğretim programlarına almış bulunuyor.

Ưniversitede kurulan kürsü öğretim programlarının amacı "bilim" olduğuna göre burada "tiyatro bilimi" haliyle başta yer alacaktı. "Tiyatro sanattır" dediler, "bilim alanına hiç girer mi ?" diye yerdiler; temel öğesinin "dram" olduğunu söylediler, bunun için de onu, edebiyat alanında incelemekte devam edilmesini istediler. Her edebiyat ancak kendi dilindeki dramını inceleyébiliyordu. Yunan-Roma edebiyatları antik dramı, Çin ve Japon edebiyatları Doğu-Asya dramını, İtalyan, İspanyol, Fransız, İngiliz, Amerikan ve Rus edebiyatları kendi dillerindeki dramları, Türk edebiyatı da Türk dilindeki dramı inceliyordu. Ama, bütün bu incelemeler, ancak, filolojik yönden oluyor, tiyatroya değindiklerinde de, ondan pek az söz ediliyor, oyun sanatı ile sahne tekniği üzerinde hiç konuşulmuyor, hele dekor, kostüm, aksesuvar ve 1şık hiç ele alınmıyordu. Neden? Çünkü asıl tiyatroyu, tiyatro yapan bu konular, edebiyatçıları ilgilendirmiyordu da ondan.. ilgilendiremezdi de. Gerçi, ayrı ayrı verilen dersler biraraya getiriliyor, yazılar, toplu bir halde ciltleniyor, hepsine genel olarak bakıllyordu ama, böylelikle bir tiyatro bilgisi değil, ancak metinler üzerinde, edebiyat ve dil açısından filolojik bilgiler veriliyor, tiyatro tarihi değil, 
dram tarihi yapılıyordu. Çeşitli edebiyatların dram tarihleri de birarada, uluslararası dünya dramının tarihini veriyordu. Oysa tiyatronun yapısında resim, mîmari, müzik ve dans da vardır. Bunun için de bir süre, tiyatronun edebiyat tarihinden çıkartılıp kültür tarihine bırakılması daha doğru bulundu; çünkü tiyatro, bütün sanatları içine alıp bir bütünü gösteriyor, yapısında, bütün kültür öğelerini veriyordu. Sanatın her bir dalı, ayrı ayrı bir araştırma konusu olduğu gibi, her biri de, mânevi bilimler alanında, birer bilim dalı olarak yer alıyordu. Her birinin ayrı bir araştırma yöntemi (metodu) vardı. $O$ halde, hepsini içine alan ve her birini yapısında organik bir bütünde işleyen tiyatronun da, kendine özgü bir araştırma yöntemi olacaktı. Kendine özgü bir araştırma yöntemi olan bir bilim dalının, bilimler alanında, bağımsız bir yeri vardır.

\section{Tiyatro Biliminin araştırma yöntemi}

"Tiyatro bilimi" kavramı, bizde henüz çok yeni bir kavramdır. Ingilizcesi theater science, Almancas1 Theaterwissenschaft'dır. Almanya'da bu adı ilk bulan ve kullanan Prof. Artur Kutscher 18781932) olmuş, Münih'te 1909 yllında, ilk olarak bir Theaterwissenschaftliche Fakultaet (=Tiyatro Bilimi Fakültesi) kurmuş, bu alanda dersler vererek, bu bilimin yöntemini araştırmıştır. Kutscher'in deyişiyle:

"Tiyatro bilimi, ancak tiyatro öğeleri üzerine kurulabilir.. yöntemi de, bilim olan, bilim araçlariyle kavranılabilen her şeyi içine alır".'

Berlin Üniversitesinde Tiyatro Bilimi Profösörü olan Hocam Max Herrmann (1865-1942), tiyatro biliminin daha çok uygulamalara yararlı olmasına çalışarak:

"Bilgilerimizi arturmaktan çok, simdiye değin hiç göz atılmamıs bir alanı araştırmamı gerekiyor" demiştir."

"Hiç göz atılmamış" çorak alan da tiyatro alanıdı. Avrupa; XX. yüzyıl başında bu alana bakmağa başladı. Biz de, hiç değilse, ayni yüzyılın ikinci yarısında gözlerimizi bu alana çevirebildik.

1 A. Kutscher: "Grundriss der Theaterwissenschaft" Vrlg. Kurt Desch, München 1931 (2. Aufl. 1936, Vorwort zur 1. Aufl. S. 432).

2 M. Herrmann: "Forschungen zur deutschen Theatergeschichte des Mittelalters und der Renaissance" Berlin 1914, S. 503. 


\section{Edebiyat Bilimi ile Tiyatro Bilimi arasındaki ayrum:}

Edebiyatın ve edebiyat biliminin deyim gücünde öz olarak logos (= Yun. söz) varsa, tiyatronun ve tiyatro biliminin deyim gücünde öz olarak mimos (= düşünceleri, duyguları yüz ve gövde anlatımı ile verme) vardır. $\mathrm{Bu}$ iki sanat alanı arasında en önemli ayrım budur. Dramın bile mimos'tan doğduğu üzerinde Hamburg Üniversitesi Profesörü Robert Petsch (1875-19) durarak görüşünü şöyle aç1klamıştır:

"Tiyatro... bir dram edebiyatı değildir. Başı sonu belli, özel niteliği ve etkisi olan genel yaşantının bir biçim içinde somutlaşttrılmastdır. Sahne edebiyàtı, içli bir bütündür. Bir bütün olarak anlaşllmak, değerlendirilmek, oynanmak ister. Tiyatro biliminin ödevi, bu bütünü, en iç varlığından ve çeşitli belirtilerinden kavramaktır... Tiyatro Bilimi, bilim olarak görkemlidir. Onun temeli de vardır. Ayni zamanda da, dramatik dünyà yaşantılarının, bu yaşantıların iç ilişkilerinin, birbirlerine olan düzenin dizgeli (sistemli) bir deyimidir." ${ }^{1}$

Demek oluyor ki, tiyatronun olduğu gibi, tiyatro biliminin de kendine özgü dili: mimos dilidir. Bunun için de tiyatro araştırmalarında, metnin yanı sıra metni aşan kımıldamalar, davranışlar, ses ve yer, söz konusudur. Tiyatroyu bunlar yapar. Her birini de üslûp bakımından yargılamak gerekir, metinlere de edebiyat üslûbu bakımından değil, dramaturgi açısından ancak bakılabilir. $\mathrm{Bu}$ anlayış kavranılıncaya değin, Avrupa'da bile uzun yıllar geçmiştir. İlk büyük adımı bu yolda, Richard Heinzel (1838-1905) atmıştır. Graz ve Viyana Üniversitelerinde Profesörlük eden Heinzel, ilk olarak araştırmalarını üç nokta dolayında topladı:

1. Dramın sanat niteliğini insan psikolojisinde saptad,

2. Seyirciler üzerinde etki derecelerini ölçtü,

3. Sanat karşısında ruh kımıldanışlarını gördü. ${ }^{2}$.

Stuttgart Yüksek Teknik Okulunda Edebiyat ve Estetik Profösörü olan Karl Weitbrecht de (1847-1904) drama, yalnizca edebiyat verimi olarak değil, sahnedeki oyuniyle birlikte, canlı, biçimi belli,

1 R. Petsch: "Die Aufgabe der Theaterwissenchaft" Hamburger Fremdenblät vom 26. Oktober und 9. November 1930 (Hochschulbeilage).

2 R. Heinzel: "Beschreibung des geistlichen Schauspiels im deutschen Mittelalter." Hamburg 1898. 
mimik bir oyun diye bakmıs ve "gözlem konusu bu mimik oyun olmalıdı" demiştir."

Leipzig Úniversitesinde Alman edebiyatı Profesörü olan Albert Köster ise daha da ileri giderek, edebiyatı tiyatro yapıtı ve "günün birinde, tiyatro tarihinin amact bütün zamanlartn ve milletlerin dramların, oynanmıs tiyatro yapıtları olarak görmek olacaktır" dedi. ${ }^{2}$ Demek oluyor ki, dram üzerinde yapılacak araştırmalarda bile gözlem, anlamlı düzenlenmiş yaşam deyimi, canlılığın deyimi olarak, davranışlardan, kımıldanışlardan başlayacaktır. Mimik sanat da, bütün öteki sanatlar gibi, dünyayı bir bütün olarak gösterir, her bir parçası, bir görüş altına sokulur, değerlẹndirilir. Kımıldayan, davranan, yalnızca gövde değil, dilini ve düzününü (ritmini) içinđe bulan insanın iş yaşamıdır; dört bir yanımızı çeviren, deyimimizi dilimizde bulan bütün insancıllığımızdır. Her şey kımıldar. Oyun oyunlaştırılırken de, küçük kımıldanışlar bile, hem de özel gölgeleri ve renkleri canlı karşıtlariyle gösterilecektir, tiyatro bilimi de bunları görecektir. Sahnede kişilerin attıkları adımlar, atılan adımlara koşut görüntülerịn düzeni, dekor parçalarının uyumlu dağılışları, bütün dereceleriyle ışıklandırmalar, hep bu kımıldanışlarda yansıdığindan, tiyatro bilimi bunları değerlendirecektir. Bunlar, dramda, nelerin söz konusu olduğunu gösterir. Filolojide ve edebiyatta önemli olan dil bakımından yorumlardır. Malzeme ya da biçim tarihi, güzellik bilimi (estetik) ve şiir bilimi (poetik) yönleri ikinci derecede gelir. Bir çok metinler, özellikle de kaba güldürüler, farce'lar, edebiyat bakımından incelemeğe değmez bile.. Oysa tiyatro bilimi için önemli olabildiği gibi değerlendirilir de.. İsviçre'li sahne yazarı Oskar Eberle metinler hakkındaki görüşünü şöyle açıklamıştır:

"Tiyatro araştırmaları için bütün metinler birdir. Yazarları ister profesyonel olsun, ister amatör olsun.. Oyunlar, ister bütün bir dram, ister yartm mimos parçaları olsun, hepsi birdir. Bize grereken şey, edebiyat tarihinin doruk basartları değil, genellikle tiyatro metinlerinin tarihini yapmaktır." ${ }_{3}$

Bunun içindir ki, tiyatro dersleri de, edebiyat tarihi derslerinden apayrıdır. Birinde değer kazanmış olan bir yazar, ötekinde değersiz sayllabilir. Nitekim; Alman edebiyatı tarihinde August Wilhelm

1 K. Weitbrecht: "Das deutsche Drama" (Grundzüge seiner Aesthetik) Berlin 1900.

2 A. Köster: »Theatergeschichte" Zeitgeist, Nr. 47, 1916.

3 O. Eberlè: "Theaterwissenschaftliche Grundbegriffe" Basel u. Freiburg 1928, S. 15 . 
Schlegel, yazdığı dramlariyle ün almış iken, tiyatro tarihinde ancak çevirici olarak adı geçer. Tersine: Büchner ile Sudermann, edebiyat tarihi için ikinci derecede yazar oḷdukları halde, tiyatro tarihinde adları ön plandadır.

Demek oluyor ki, tiyatro, edebiyattan apayrı ve bambaşka bir kaynaktan geldiğinden, her şeyden önce de oynanması gereken bir konu olduğundan, tiyatro bilimi daha çok oyuna bakacaktır. Oyunun yöntemleri, metin inceleme yöntemlerinden apayrı olduğundan da, tiyatro bilimi hiç bir bakımđan edebiyat bilimine bağlanamaz, araştırmalarını, incelemelerini edebiyat bölümünün içinde yapamaz.

\section{Tiyatro Biliminin Ödevi}

Max Herrmann, tiyatro biliminin ödevini şöyle açıklar: “Geçmişte oynanmiş olan bir oyun, sahnede nasll gösteril- . miştir? Bunu bütün bölümleriyle yeniden canlandırmak gerekir. Bunun için de eldeki gereçte boşluklar varsa, bunları tamamlayıcı gereçle doldurmalı. Gerçi, gereci düzenlemek ve boşlukları doldurmak için kullanilan araçlar, filolojinin ve tarihin araçlartdır ama, bu araçlarla elde edilen kültür özellikleri ve sanat olaylart değiştirilir, desteklenir ve açıklantrsa, o zaman tiyatro tarihi araştırmalarında ve incelemelerinde, bu sanat özelliklerinde bütün inceliklerin hakkınt vermek için zorluk çekilmez." ${ }^{1}$

Demek oluyor ki, Max Herrmann'a göre, tiyatro biliminin ödevi: belli bir çağda oynanan bir dramın sahne özelliklerini, filolojik-tarihsel araçlarla araştırıp bulmak, boşlukları döldurmak, oyunu, zamanında olduğu gibi yeniden kurmaktır. Bunun için de yürünecek yol iki basamakta gösteriliyor:

1. Oyunun geçtiği yeri, renk, kalıp ve 1ş1k öğeleri ile canlandıran sahne dekorları ve döşem (dekor) gereğiyle kullanılan donatım (aksesuvar) ve makinalar araştırilacak..

2. Oyun sanatı incelenecek ve bu sanatın maske, kostüm gibi özel araçları gözden geçirelecek, bu sırada da okunan metnin genel konusu ve sahne özellikleri dikkate alınacak.

1 M. Herrmann: »Forschungen zur deutschen Theatergeschichte des Mittelalters und der Renaissance" Berlin 1914, S. 5. 
Ama iş, yalnız bu iki basamakta bitmiyordu. Kuruluşun doğru olduğunu gösterebilmek için, yazarın açıklamaları, rejisörün notları ile çağın yargıları da gözz önünde bulundurularak resimleri görülecek, taslakları çizilecek, maketlerle gösterilecekti.

Resim ve maketler üzerinde, özellikle Albert Köster durmuş, eski dramların tarihsel sahneye konuşlarını maket ya da kâğıt üzerinde, çağında nasıl oynandığını göstermeğe çalışmıştır.

"Bilim açısından söz konusu olan şey: geniş ama gene de dizginli bir hayal gücü ile, her şeyden önce de kestirmeler üzerinde kuskulanmak, kuşku ile de sağlam görüşlere varıp dramı, oynandığ gibi canlandırmak, yazarın ve çağdaşlartnın gözleri önünde sahneye konulduğu gibi tanitlamakttr." ${ }^{1}$

Kuşku, Descartes felsefesinden geliyordu. Onun felsefe yöntemi, bütün bilim alanlarının yöntemi olmuşstu. Tiyatro araştırmalarında da doğruya varabilmek için XX. yüzyıla değin değerini yitirmemiş, faydalı olmuştur. Onun matematik yöntemi (analitik geometri) nasıl önce düşünceleri parçalar ve bunları yaratan öğeleri birer birer ayırdıktan sonra yeniden kurmağa çalışırsa, oynanmış bir oyunun parçaları da elde edilir edilmez, sağlam düşüncelerle biraraya getirilecek, her parçanın niteliği bir başka parçadan çıkartılacak ve yoliyle, titizlikle birleștirilecektir. O zaman ancak, tiyatro alanında, doğru bütün kurulabilir. Titizlik göstermeyip, düşünceler zinciri arasına yanliş bir düşünce girince, nasıl son doğru bilgiye ulaşılamazsa, parçalar arasına da yanlış bir parça girdi mi, bütünün yapısı aksar. Amaç, aslına uygun, doğru bir bütünü yeniden kurarak, bunu kültür tarihine mal etmektir.

Böylelikle Max Herrmann ile Albert Köster, tiyatro bilimi alanında, araştırma yöntemi yolunđa, iki öncü savaş̧̧ı idiler.

Oyun sanatı üzerinde çağdaşların tanıtmalarına büyük çapta önem veren tiyatro eleştirmeni Monty Jacobs (1875-1945) olmuştur. Kendisi bu konuda şöyle demiştir:

"Teknik yardimcı araçlar olmaksızın, bir sahne sanatı tarihi yazılması söz konusu olunca, o zaman, ister istemez çağdaşlarının söylediklerine dayantlır. Bilim düzeni için sağlam dayanak çağdaşlarm sözlerindedir, yoksa dosyaların karışılığı ve anekdotlartn gevezelikleri içine gömülür sahne sanatı.

1 A. Köster: "Theatergeschichte" Zeitgeist, Nr. 47, 1916. 
Ama çağdaşlar yanlış yapmayan yargıçlar gibi değil, ancak tantt olarak çağrtlacaktır. Bilginler, onlart savunacak, söz ile karşı sözde kişisel yaşantı doğruluğunu gösterecektir." ${ }^{1}$

Demek oluyor ki karar, çağdaşların ruhlarından alınacaktır. Son zamanlarda, plak ve filmden de çok şeyler beklendi. Bunun için de gereçler derlendi. Derlenenler arasında Eugen Wolff'un topladıklarınt, ilk olması bakımından, tarihce değeri vardır. Ama, bunların üzerinde, her şeyden önce de tiyatro üslubû açısından durulması gerekiyordu. Geçmişte oynanmış başarılı bir oyun canlandırılacak ama, bu filolojiktarihsel bir çalışma olmıyacaktı. Yeniden canlandırma, bugün olacağı için, çağdaş tiyatronun iyi bilinmesi gerekiyordu. Max Herrmann da bu noktaya işaret etmişti:

"Her tarihsel düzende, gerçekten canllltk, ancak çă̆daş olaylardan elde edilebilir.".

Petsch.de, oyunun dış görünüşleri için keskin bakiş istiyordu. Bu da gene, gözleme mimikten başlanacağını destekliyordu. Bir de bilim adamının tanıtlama yeteneği söz konusu idi: Oyunun niteliklerini belirterek her inceliğini anlatacak, anlatarak resmeder gibi gözlerimizin önüne serecektir. $O$ zaman ancak tam bir oyun tablosu canlanabilir. Ama işte tiyatro biliminde güç olan da budur. Hele geçmişte oynanmış bir oyun için bu güçlük. daha da artar.

\section{Tiyatro bilimi alaninın konuları}

Tiyatro bilimi alanının ana konuları şunlardır: Tiyatro Tarihi, Dramaturgi, Uygulama (Tatbikat), Tiyatro Eleştiriciliği, Öğrencilerin Deneme Sahnesi.

1. Tiyatro Tarihi: : Tiyatro Bilimi içindedir, tarih, bilimin bir bölümüdür. Yalnız ne var ki, tiyatro alanında bilimsel çalışmalar, tiyatro tarihi yapılmadan yapılamaz. Tiyatro bilimin asıl işi, tarih yapmak değil, geçmişte oynanmış oyunları yeniden kurmaktır. Tarih, tiyatro biliminde ancak bir yol, bir araçtır; bütün çağların, ulusların tiyatrosunu: sahnesini, oyun sanatını, dansını ve tekniğini öğretir. Bir sanat tarihi, bir müzik tarihi olduğu gibi, bir tiyatro tarihi de vardır; bu da gene edebiyattan ayrıdır.

1 M. Jacobs: $» D e u t s c h e$ Schauspielkunst. Zeugnisse zur Bühnengeschichte klassische Rollen." Leipzig 1913, S.1.

2 M. Herrmann: »Über die Aufgaben und Ziele eines theaterwissenschaftlichen Universitaetsinstituts." Szene, 1920, Heft, S. 130 ff. 
Max Herrmann, amatörlerin ve köylülerin oyunlarını tiyatro bilimi alanından çıkararak halk bilim'i alanına vermiştir. Tiyatro severlerin oyunlarında "sanat yoktur" diyerek, bunlan bilim alanına sokmamıştır. Oysa Artur Kutscher, hepsinin tiyatro bilimi alanında yeri olduğunu söyler. ${ }^{1}$ Değil mi ki buṇlar da ayni kökten: mimos'tan gelmektedir; özleri đeğil, ancak dereceleri başkadır. Meslekten tiyatroculuk, ancak XVII. yüzyılda gelişmeye başladı.

Tiyatro tarihçisi, eskiçağ, ortaçağ ve yeniçağ tiyatrolarını ele alacak, bütün ulusların: Yunanlıların, Romalıların, Hintlilerin, Doğu Asyalıların, İtalyanların, İspanyolların; Fransızların, Hollandalıların, İngilizlerin, Almanların, Danimarkalıların, İsveçlilerin, Norveçlilerin, Rusların, Amerikalıların tiyatroların inceleyecek, hem de her birine, ulusal bakımđan zaman özellikleri, kendi ilişkileri, etkileri, gelişmeleri ve çağları içinde bakacaktır. Tiyatro tarihçisi, hem dinsel, hem de dünya tiyatrosunu dikkate alacak, eğlence için kurulan tiyatrolara olduğu gibi, sanat tiyatrolarını da gözden geçirecek, halk ve toplum tiyatrolarını inceleyecek, kukla ve gölge oyunlarının sahne tiplerini ve cihazlarını, oyun verişlerini, seyircilerini ve basınını bilecektir.

Tiyatro tarihçisi, yalnız kendi ulusal, yalnız Alman Fransız ve İngiliz tiyatrosunun tarihini de yapabilir. Yalnız Türk sanatı ve Türk müzik tarihi yapıldığı gibi, yalnız Türk tiyatrosunun da tarihi yapılabilir; belli bir dil sınırı içinde özel olarak nelerin başarıldığı gösterilebilir. Ama işte bu da gene ancak karşılaştırmalarla değerlendirilebilir. Bilinen bir şey varsa, özel temeller kavranıldı mı, bunlar genel olana götürür. Hele bizim tiyatromuzda yabancı oyunların oynatılması ve sahne yönetiminin hâlâ yabancı rejisörlere verilmesi söz konusu olduğundan, tiyatro tarihimizde, yabancilarla bağlantılar, edebiyat tarihimizde olduğundan daha çok ve daha önemlidir.

Cumhuriyetten sonraki tiyatromuz, yabancı tiyatro kültürü bilgisi olmadan araştırılamıyacağı gibi, anlaşılamaz da..

Albert Köster, tiyatro tarihi alanını üçe ayırır:

1. Dram gelişimine bağlı genel bir sanat kurumu olarak alınan ve izlenen tiyatro tarihi,

2. Teknik sorunlarla kendi içinde bir dünya olarak alınan ve izlenen tarihi yapı işleri, oyun yerleri, sahne süsleri, dramaturgi ve reji, oyun, kostüm ve mimik.

1 A. Kutscher: 》Grundriss der Theaterwissenschaft" Vrlg. Kurt Desch, München 1931 (2. Aufl. 1936. S. 46). 
3. Tiyatro yöneticisi, sahne sanatçısı ve yöresel tiyatrolar üzerine biyografik bilgiler veren tiyatro tarihi..

Son bölüm çok önemlidir; Tiyatro tarihinin kaynaklarına götürür, bilim ve donatım gereçlerini elde etmeğe çalışır, bibliografya verir: Elkitapları, yerli ve yabancı derlemeler, yayın dizileri, dergiler, yardımcı kitaplar üzerine bilgiler sağlar. Ama Köster için en önemli bölüm ikinci bölümdü: Tiyatronun, kendi içinde bir dünya olarak alınan ve izlenen bölümdü:

"Son yıllarda, gitgide daha çok, en önemli sorunları, bu üç bölümün ortasindaki bölümde olduğu, asll anlamda sahne tarihi olan bu bölümün sorunlart üzerinde durulmast gerektiği anlaşlld. Ama işte bu bölüm üzerinde de pek çok şey bilemiyoruz. Son sorunlar ancak, bu üç bölümün sorunlartnl ayrı ayrı değil de, birinden ötekine köprüler kurmakla çözülebileceği kantsindayım." 1

Tiyatro tarihi, tiyatro araştırıcıları için olduğu gibi, tiyatroyu meslek olarak seçmiş olanlar, herkesten önce de, yaratıcı olarak tiyatro ile uğraşanlar ve uğraşacaklar için tiyatro tarihi zorunludur. Hele dramaturg ile rejisörün, dram tarihini iyice bilmesi gerekir; çünkü o, eski oyunları da bugünün canlı tiyatrosu için düzenleyecektir. Eski oyunun hangi kafadan, hangi ilişkilerden çıktığını, zamanında ne biçimde oynandığını bilmesi gerekïr rejisörün, eskiyi günün diline ve beğenisine aktarırken de, eski tiyatronun dilini, bir de, sahne ve oyun sanatının tarihlerini bilecektir. Tiyatro tarihi, dramaturg ile rejisöre, yaratıcılığı için geçmişten bilgiler verir, olaylar zincirinde, ilk ilişkilere değin götürür ve gereçlerini belirtir. Tiyatro tarihinin ölçülmez değeri, onun öğreticiliğindedir:

1. Karşılaştırmayı gösterir,

2. Birleştirmeyi ve ayırmayı öğretir,

3. Mimik olanakları belirtir,

4. Çeşitlilikte bir iç birlik olduğunu ve bunu aynı zamanda görmek gerektiğini koşullar,

5. Gelip gitmeleri, bilinenlerin, görülenlerin gene geldiklerini ve gene gittiklerini, sanat olaylarının durmadan dolaşımını aydinlatır.

1 M. Herrmann: "Theatergeschichte" (Aufsatz) X, 1920, 8. Heft, S. 30. 
Tiyatro tarihi de bütün öteki tarihler gibi: edebiyat tarihi, sanat tarihi, müzik tarihi ve kültür tarihi gibi insanı zenginleştircrei yükseltir, yaratıcıyı iki bakımdan etkiler:

1. Onu canlandırır, kımıldatır ve yaşama bağlar.

2. Kendine, insanlara ve zamana olan inancını arttırır. Leipzig Ưniversitesi Profesörü Adolf Harnack, 1917 y1lınáa, Münih'de toplanan Alman Müzeleri Derneği'nin Genel Kurulunda (bu derneğe tiyatro müzeleri de girmişti) etki konusunda şöyle söylemiş:

"Insan özendiren ve sürükleyen şeylerin insana uymadı̆̆ doğru ise... neden tarih ögrenilir, sorusuna şu cevap verilebilir: Tarihin boyunu uzatmak için denilebilir. Bundan da, bilgiyi arttıran her tarihin fağımızın tarihi olmast gerektiği sonucu çıkar." "

Tarihe uzanmak, tarihi uzatmak şu demektir:

1. Günün yaşamını engelleyici olaràk etkilediği yerde, geçmişi birakmak,

2. Günlük yaşamda doğru olanı yapmak,

3. Geleceği bütün ayrıntılarıyla hazırlamak.

Bunun için de işte, geçmişe, tarihe olan iliş̧isi içinde bir yargıçlık görevi verilmiş oluyor; gelecek için de onun bir ereği oluyor; çünkü, ancak geleceği hazırlayan bilimin yaşamağa hakkı vardır. Her alanın tarihi gibi, tiyatro alanının tarihi de sonunda bilgi ve bilimin kaynağıdır.

Geçmiş, doğru kavranılmakla, içinde yaşanılan çağ ile gelecek de verildiğinden, sanat akımları doğal olarak hep karşıtlar içinde gelişir. Karşıtları kuram (nazariye) verir. Her biri de uygulamalarla (tatbikatla) gösterilir. Kuram, burada, estetiktir, üslûp bilgisidir. Tiyatro bilimi alanında da "dramaturgi" kavramıyla karşılanır.

2. Dramaturgi: Bu kavrami, ilk önce, Almanya'da Lessing kullanmıştır. $\mathrm{O}$, bu kavram altında, dram ve oyunlar üzerinde bilimsel konuşmalarla, estetik kuralları ayrı ayrı, her oynanan oyunlarda göstermeği anlamıştır. Onun "Die Hamburgische Dramaturgie" (= Hamburg Dramaturgisi) bu anlayıșla yazılmıştır. Böyle bir dramaturgi ile de Lessing'den sonra Tieck, Rötscher, Hebbel ve Otto Ludwig uğraşmıştır.

1 A. Kutscher: "Grundriss der Theaterwissenschaft" S. 442. 
"Dramaturgi" kavramının bugünkü anlamını ise ilk önce Johann Elias Schlegel vermiştir. "Schreiben von Errichtung eines Theaters in Kopenhagen" (Kopenhag'de Bir Tiyatronun Kuruluşu Üzerine) adlı yazısında o, şöyle demiştir:

"Komedyalartn ve komedya oynayan kurumlarin bakımı, yalnizca bir oyuncuya birakllmamall. Bu is saraylarda verilen operalarda ve komedyalarda olduğu gibi, oyun seçecek, kötü ile kaba şakayl, ince ile iyi buluşlarl birbirinden ayıracak kadar sanattan anlayan, bilgili ve sayllan birisine verilmeli. Böyle biri olmadığı sürece, her zaman kötü oyunlar seçilir, kötü düzenler kurulur, oyuna yeni başlayan tiyatrolar da, kıskançlıklar ve kötü yönetim yüzünden kapanır."

Dramaturgların ödevi, yalnız oyun seçmek olmamakla beraber, Schlegel burada, önemli bir noktaya parmağını basmış oluyor.

"Dramaturgi" kavramının bir üçüncü anlamı da, dram sanatının bilimi, onun kuramları, kanunları demektir. Bu anlamda bu kavram ilk önce Alexander Gottlieb Baumgarten (1714-1762) "Sciagraphia encyclopaediae philosophica" (=Felsefe Ansiklopedisi Bilgisi) adlı çalışmalarında kullanmıştır. Burada o, şöyle demektedir:

"Dramaturgi, dram bilimidir. Aksiyon için olduğu gibi makyaj ve dekor için de kurallar sağlar. En çok da pantomim bilgisine önem verir: düsünceyi seyircilere, sözden çok jest ve hareketlerle bildirmek ister. Bundan da 'mim' ve 'pantomim' sanatı doğmuştur." 2

Bununla Baumgarten, Almanların sistematik estetiğinin kurucusu oldu. İlk olarak da bilimsel dramaturginin ana düşüncesini getirdi, dramaturgi ile edebiyat gözlemlerinin ayrıldığı noktayı gösterdi.

Ilk temel bilgileri veren kitap da Hugo Dinger'in "Dramaturgie als Wissenschaft" (Bilim olarak Dramaturgi) adlı kitabıdır. ${ }^{3}$ Bu kitap, arı bilim çerçevesi içinde tutulmuş ve dağınık bir halde bulunan bilimsel çalışmaları birleştirmek, dramaturgiyi, düzenli, ereği bilinçli bir disipline yükseltmek istemiştir. Uygulama ödevini Baumgarten, kuram bilgisinin sonuçlarını, dramatik sanata uygulamakta ve bunu teşvik için kullanmakta görmüştür. Derslerinde kuramsal bilginin

1 J. E. Schlegel: "Schreiben von Errichtung eines Theaters in Kopenhagen"

2 Iki cilt, Leipzig 1904/05.

3 Magdeburg 1769, S. $107 / 08$. 
dışına çıkıyor, uygulayıcı ereklere yöneliyordu. Araştırmalarına öğrenciyi de katıyordu. Amac1: dramatik sanatla herhangi bir yolda uğraşmak istiyenlere, kuramlanı öğretmek ve her birini, bilim alanı için yetiştirmekti. Böylece dramaturgi uygulanacak olan sahne yararına çalışan tiyatro bilimi alanının bir bölümü oldu ve tiyatro tarihinden apayrı sonuçlar vermeğe başladı:

Tiyatro tarihi: ayrımları bildirir, zaman içinde gelişeni, gelişmeyeni, değişeni değişmeyeni gösterir. Geniş, yorucu bir yolu vardır onun; ereği de bütünlemektir. Bunun için hep bütünleme kaygısıyle anlatır. İçindeki yaşanmış tehlikeleri de, ders olsun diye bildirir; bugünün buluşlarının, yarınkilerle anlamlarını yitireceğini vurgular.

Dramaturgi ise: oynanacak olan oyunun metnini, edebiyat ya da filolojik yönden değil de, sahnede oynanması bakımından, oyun için elverişli olup olmadığını söyler. Ortak olanı, kalacak olanı aydınlatır. Bütünü iki eliyle kavrar. Onun için dramatik üslûp söz konusudur. Soruları şunlardır:

1. Metin, ne dereceye değin dramatiktir?

2. Sözler ne veriyor?

3. Dramatik metin için ne gibi oyun olanakları var?

4. Metnin biçimi, sahne biçimine uyuyor mu?

5. Diş biçim, iç biçime uyuyor mu? Uyuyorsa nerelerde uyuyor ve nerelerde uymuyor?

6. Uyan nedir? Uymayan nedir?

Oynanacak bir oyun üzerinde bütün bu sorulara cevap vermek kolay değildir. Dramaturgiden geçmeden sahneye konan oyunlar, sahne adamlarını çok yanılttıkları ve şaşırttıkları olmuştur.

Tarihsel olayların, mutlaka kuramsal olaylara karşı olmaları gerekmez. En eskinin de mutlaka en eski olduğu söylenemez. Insanın doğasal yapısı ile sanat yapisı üzerinde, halk bilgisi alanında yapıllan karşılaştırmaları̣n sonucunda, tiyatronun başlangicı dinsel törenlerde, rakıslarda, genel olarak da halk oyunlarında bulunmuştur. Ama bunlar da ancak tarihsel tanitları vermektedir.

Dramaturgi (üslûp bilgisi), tarihten daha başka sonuçlar verdiğinden, sanat ve bilim gözlemi alanında başlı başına önemli bir rol oynar. Ama yalnız dramaturgi ile de yetinilemez; çünkü onun da verdiklerini tarihsel alana yerleştirmemiz ve bu alandan gelişimine bak- 
mamız gerekir. Her ikisini de yalnız başlarına alamadığımızdan, ikisinin, birbirinin olduğunu, birlikte incelemek gerektiğini gösterir. Tarih, değerini dramaturgi ile alır; dramaturginin de gelişimi, tarihsiz gösterilemez. Dramaturgi, dramın iç ve dış yapısını incelediğinden, kişisel olanı belirtir ve her şeyin insan kafasına, duygusuna, hayal gücüne, sonunda bütün yapısına bağlı olduğunu gösterir. Her yazarın, düşüncelerini, duygularını, yaşantılarını kişisel bir formüle sokuşu, billurlaştırması vardır. Kalan da budur işte. Ayrıca, üslûp bilgisinden de kendi tarihi yapılır. Bunu incelemek, tiyatro alanı biliminde öğretimi canlandırır, derinleştirir.

3. Uygulama (Tatbikat): Tiyatro konusunda yapılan her türlü bilimsel ve sanat çalışmalarının, kendi gerçeklerine: sahne bilgisine, sahne tekniğine, sahne işçiliğine, sahne tekniği araçlarına, dekora, 1şıklamaya bir ilişkisi vardır. Bunun içindir ki kuramsal incelemeleri yaparak yargıları izleyen dramaturgi araştırmaları yanında bir de uygulama (tatbikat) bilimsel öğretimde zorunludur. Hiç değilse, sanat tarihinin yaptığı gibi, projeksiyonla, saklanmış eşyalarla gereçler gösterilecek, resimler, kitaplar elden ele dolaşacak, kumaştan, kartondan, tahtadan örnekler verilecektir. Bu da haliyle önceden toplamayı koşullar. Bundan ötürü, üniversitelerde, tiyatro kürsülerinin yanında enstitülerin bulunması, kitaplıkların yanında arşivlerin kurulması, küçük çapta da olsa müzelerin açılması zorunludur.

Bugün, Avrupa'da, artık pek çok tiyatro koleksyonu var. Özel önemi de projeksiyonlar taşır. Tiyatro yapıtları, teknik kuruluşlar, sahneleri eşyaları yerlerinde görmek üzere geziler düzenlenir; halk bilgisi kültür ve sanat tarihi müzelerinde, resim galerilerinde, gravür kabinelerinde grafik kolleksyonlar görülür. Tiyatro müzelerinde de, özel olarak sahneler, dekorlar ve kostümler, tarihi gelişimi içinde izlenir. Bunlardan başka atelyeler, fabrikalar, okul, dans ve oyun yerleri gezilir, her birini görmek için diş ülkelere bile toplu halde gidilir. Tarihi tiyatro yerlerini gezmek, açılamaları yerlerinde dinlemek, özel tiyatro sorunlarını yerlerinde düşünmek, dili, şarkıyı, duruşları, jestleri yerlerinde kontrol etmek, repertuvarları ile oyun tarzları özel olan büyük kentlerin tiyatrolarında temsiller görmek, ilçelerdeki, halk ve amatör tiyatrolarına giderek, bunlarda, yalnız sahnede verilen oyunu değil, seyircilerini ve tutumlarını da gözlemlemek gerekir. Danslar, törenler, halk töreleri, kıyafetleri içine girecek, tiyatronun müzelik değer olarak ne varsa, her şeyin görülmesi gerekir. 
4. Tiyatro Eleştiriciliği: Tiyatro bilimi, mânevi bilimler alanında yer aldığından, üniversitelerde, bu bilimlerde meslek edinmek için geçilmesi gereken yol, tiyatro bilimi için de söz konusudur. Her şeyden önce de bağımsız çalışmak, özgür düşünmẹk için, bilimin temellerini veren bilgiler elde edilecek, ondan sonra günün tiyatrosunda eleștirme ile de uğraşılacaktır. 1894 yılından bu yana, Münih Üniversitesinde Adolf Sandberger "Analyse musikdramatischer Kunstwerke unter tunlicher Berücksichtigung des Repertoires der königlichen Bühnen" (= K̇raliyet sahnesinin repertuvarı gözönünde bulundurarak müzikli dramların incelenmesi) adı altında dersler vermiştir. Gene Münih'te doçent olarak Roman Woerner de (1863) 1899 yllının yaz semesterinde: "Literarhistorische Übungen am modernen Drama mit besonderer Berücksichtigung des Spielplans unserer Bühnen." (= Sahnelerimizin repertuvarı göz önünde bulundurularak, modern dramlar üzerinde edebiyat tarihi bakımından incelemeğe alştırmalar) ad altında dersler vermiş, Artur Kutscher de bu dersleri devam ettirmiştir. Bu türlü dersler, tiyatro bilimi açılarını verir, dikkati ve anlayışı arttırır; yalnız eleştiri yapmaz, yalnız yerleri ve yaban$\mathrm{cl}$, yeni ve eski oyunlar üzerinde durmaz; yalnız ilk temsiller, yeniden sahneye koyuşlar, tekrarlamalar üzerinde konuşmaz, ayni zamanda da, reji, oyun sanatı, sahneye konuş, dekor, ışı, teknik ve ve makinayı, seyirciyi de içine alır ve sahnenin bütün çalışmasını, deyiş sanatını, sanat araçlarını ve tiyatro olanaklarını yargılar. $\mathrm{Bu}$ türlü çalışmalarda, özel olarak, sorunlu oyunlar seçildiğinden, araştırmalara, üslûp tarihi açıklamalar, sahne bilgisi üzerine dersler yardım eder; taslaklar, desenler, grafikler, projeksyonla gösterilir; bu arada rejisörler, oyuncular, sahne dekorcuları ve teknisyenlerle kişisel temaslar çok faydalıdır. Amaç: Öğrencilerin duyularını tiyatroya yöneltmek, bu özel dünyada, onlara görmesini, işitmesini ve duymas1nı öğretmektir. Açıklayanın yanına bir ikinci açıklayıcı daha verilir; aralarında tartışmalar yaptırılır. Görüşlerin karşılaşmasından, doğru olan aydınlanır. Ama, bütün bunlar, kişisel, sağlam bir sanat yargısı elde etmek için değil, daha çok ön koşullara ve tiyatro olanaklarına yanaştırmak içindir. Uygulayıcı tiyatro eleştirisi, ayrı ayrı ya da toplu olarak yapılabilir. Toplu olarak ancak, temsil birlikte görüldüğünde olur. Bu türlü eleştirmeler, sonunda yazıya dökülerek "rapor" ya da "deneme" biçimine de sokulabilir. Yalnız ne var ki, seyirciler, hep ayni seviyede değillerdir; yargıları bir olmaz. Eleştirinin düşük ellere düşmemesi için de, okuldan geçmesi gerekir. 
5. Öğrencilerin Deneme Sahnesi: Tiyatro bilimi alaṇında, öğrencilerin kendi oyunları da söz konusudur. Okullar ve Úniversiteler kurulduğundan bu yana, öğrenciler, hep oynamışlardır. Meslekten bir çok tiyatrocular arasında değerli kişilerin hep bu akademik çevrelerden yetiştikleri görülür. En çok da akademik-dramatik derneklerden... Ủlkemizde bu görevi Cumhuriyetle birlikte kurulan Halkevlerinin tiyatro kolları yapmıştır. Son doksan yıl içinde, Berlin, Münih, Viyana ve daha başka üniversitelerde yetişenlerin sayısı pek çoktur. Hepsi de modern dram için savaşmışlardır. Oyunlarını çoğunlukla okuduklan dershanelerde ya da kiraladıkları bir sahnede halka vermişlerdir. Biz de böyle başladık: İlk temsilimiz, Ankara'da Devlet Tiyatrosunun bir sahnesinde (Beşinci Tiyatroda), ikinci temsilimizi de TürkAmerikan Derneğinin sahnesinde verdik.. Oyuncularımız, yalnız Tiyatro kürsüsünün öğrencileriydi. Avrupa U̇niversitelerinde, baş rolleri, meslekten oyuncuların da katıldıkları olurmuş. Üniversite temsillerinde, hep sanat kaygısı başta gelmiştir. Bunun için de, bu temsiller, başarılı olduklarında, seyircilerin sanat anlayışları gelişir. Sanat kaygısı, hiç kuşkusuz, küçük büyük her tiyatroda vardır. Onun içindir ki, Üniversitelerin getirdiği bir yenilik değildir bu.. Ancak büyük sahnelerin oynadıkları küçük, modern oyunları, çoğu kez de, öz dillerinde oynamalan bir yenilik olabilirdi. Kanımca, üniversiteler, temsillerinde de daha çok bilimle ilgilenmeli ve geçmiş denilip oynanmayan, ama, tiyatro tarihinde önemli bir yeri olan klasik oyunları ele alıp, onları, tarihsel gerçeklere ve araştırmalara dayanarak, olabildiği değin zamanında oynanmış biçimleri, ama yeni yorum ve günümüzün beğenisi ile sahneye koymağa çalışmalı. Böyle oyunlar, ancak üniversite çerçevesi içine yakışır ve öğretime faydalı olur. Münih'de oynanan ve dilimize "Adamotu" diye çevrilen Machiavelli'nin "Mandragola"sı ${ }^{1}$ bu tip oyunlardandır. Bu tip oyunlar için üniversite tiyatroları isteyenler arasında Jocza Savitz bașta gelir; Shakespeare öğretimi için isteklerini şöyle belirtmiştir:

"Shakespeare, üniversitelerde, yalnizca filoloji ve üslûp eleştirisi bakımindan takrir ve seminer!erle değil, yenilenmis bir Shakespeare-sahnesinde oyunlartnı oynamakla öğretilir. Bu bir deneme sahnesi olarak halka da, orijina! Shakespeare'i verebilir. Üniversiteler, yalnız geleceğin meslekten oyunculartnin temel-bilgilerini kuramlt incelemelerle aldiklart

1 Machiavelli: "Adamotu" çeviren: Samim Sinanoğlu, M. E. B. Dünya Edebiyatından Tercümeler, İtalyan Klâssikleri: 15 Istanbul 1951, 
yerler değil, ayni zamanda uygulamalı çalışmalar arasından yetişen rejisörlerin de ögrenim yerleri olmall.."

Berlin Üniversitesinin tiyatro Kürsüsünü yöneten Prof. Dr. Hans Knudsen (1886), Max Herrmann'ın öğretimine göre, bir tiyatro bilimi enstitüsünün temsiller vermesini ancak, bilimin desteklediği, geçmiş, teatral başarıları doğru olarak kurmak kaygısı söz konusu olduğu oranında doğru bulur. ${ }^{2}$ Pfeiffer - Belli de, Frankfurt Úniversitesi'nin temsillerinde, oyunculuğa çok önem verilmediğinden yakınır ${ }^{3}$. Buna karşılık İgnaz Gentges, öğrenci temsillerinin halka gösterilmesini ${ }^{4}$ ve Üniversite kentinin dört bir yanını sarmasını istemiștir. Köln Úniversitesi'nde de Carl Niessen (1890), kendi rejisörlüğü altında, öğrencilere olgun temsiller verdirtmeğe çalışmıştır ${ }^{5}$ İkinci Dünya Savașından sonra, biraraya gelen öğrenci topluluklarının, gerçi tiyatro bilimi ile ilgileri yoktu, ama, hiç değilse sanat kaygıları vardı. Erlangen, Frankfurt, Göttingen, Hamburg, Heidelberg, Jena, Kiel, Mainz, Münih ve Würzburg üniversitelerinin öğrenci sahneleri parlamıștı. Bütün bu deneme (Studio) sahneleri, 1947 yılinda, Würzburg'da buluşarak, büyük bir toplantı yaptılar, konuşmalarının başında oyunlarına sanat kaygısı güden rejisörler çıkarabilmek için, aralarına, meslekten oyuncular ve rejisörler de almak istediklerini tartıştılar. Bunlarla birlikte çalışarak, birlikte oynayarak, dramatik edebiyatın sanat biçimlerini, oynanış inceliklerini öğrenecekler, önce öğrenciler karşısında oynayacaklar, sanat seviyesine ulaştıklarında da, halka temsiller vereceklerdi. Kararlarını beş madde de sıraladılar:

1. Temsilleri, meslek tiyatroları için ekonomik yönden çok pahaliya mal olacak olan antik çağdan günlerine değin olan oyunları belirtmek ve bunlara, her birini yeniden işleyerek meslekten tiyatrolara dikkatlerini çekmek..

2. Meslek tiyatrolarında tutunarak çok oynanmış olan oyunlara yeni açılar ve olanaklar sağlayabilmek için reji bakımından denemeler yapmak.

1 J. Savitz: "Shakespeare und die Bühne des Dramas" Bonn 1917.

2 H. Knudsen: Das Studium der Teaterwissenschaft in Deutschland" Charlottenburg 1926, S. 19.

3 Über theaterwissenschaftliche Institute "Die Szene, Heft 3.

4 Y. Gentgens: "Theaterwissenschaftliche Arbeit im Reich" Baden - Badener Blätter, 1924, Nr. 38. 
3. Zamanın düşünce akımları ile çağdaş oyunlar ve yazarları üzerinde tartışmak.. Bu sırada da gençliği, son yirmibeş yılın yerli ve yabancı dramatik oyunlarına yöneltmeğe çalışmak:.

4. Henüz oynanmamış oyunlardan, șöz konusu olanı, yazarı, tiyatrosu ve sahnesi ile birlikte denemek ve onu sahne için hazırlamak..

5. Teknik Yüksek Okulların deneme (studio) sahnelerine her şeyden önce teknik olanakların gelişiminde denemeler yaptırmak, sonuçları da öteki studio sahnelerine bildirmek..

Burada da gene modern dram, çalışmaların başında geliyordu. Ama, Artur Kutscher'in, öğrenci oyunları konusundaki görüşü bambaşka idi: $O$, şöyle diyordu.

"Öğrenci oyunlart, oyuncu ve rejisör olarak sanat çalışmalarına yönelmemeli. Bu türlü çalışmalar önceleri, üniversite dişında, sonraları da tiyatroda kavranması ve ögretilmesi gerekir"'. Kutscher, öğrencilerini ikiye ayırır:

1. Gençliklerinin oyun iç̧tepisini yaşamak isteyen öğrenciler,

2. Üniversite araciyle, tiyatroya, meslek olarak kendilerini hazırlamak isteyen öğrenciler.

Birinci Grup: Gençliklerinin oyun içtepisini yaşamak isteyen öğrencilerdir ve bunlar çoğunluktadır; haklı olarak da kendi başlarına buyrukturlar. bir çok hallerde başarılı olur bunlar ama, bu tip öğrencilerle uğraşmak üniversitelerin görevi olamaz.

Ikinci Grup: Üniversite araciyle tiyatroya meslek olarak kendilerini hazırlamak isteyen öğrenciler, okumak, kendilerini yetiştirmek isterler. Üniversiteler, kendilerini, bu türlü öğrenciler için sorumlu tutar. Bunların erkenden, oyunları bilmeleri, tiyatrolarla ilgilenmeleri gerekir; böylelikle ancak onlar oyunları, en iyi bir yolda yorumlayabilirler. Tiyatro bilimini bırakamaz bunlar. Ağırbaşlı bir tiyatro bilimi, çalışma yerlerinde, yalnız tarih bilgileri vermek için değil, üslûp bilgisi gözlemler yaptırmak için de bir deneme sahnesi ister. Burada, ögrencilere, kuramların temelini veren, tiyatro tarihi okunan ve onları, bir oyun topluluğu halinde, ellerinde belli metin ödevleri

1 A. Kutscher: "Grundriss der Theaterwissenschaft Vrlg. Desch, München 1931 (2. Auf1. 1936). 
olarak oyun sanatının sorunları, dramaturgi, reji, sahne ve tekniği hiç unutturmamacasına oynayarak öğretilir. Öğrenci ile hoca arasında, başka hị̧ bir bilim dalında görülmiyen bir bağ kurulur. Oyuncu topluluğu bu bağ içinde bir Kurum olarak çalışır. Böyle bir bă̆ içinde çalışan Kurum da, öğrencilerin mesleğe yetişmelerinde gerçekten verimli olur. Bu türlü oyunları ilk olarak Münih'de hiç meslekten kişiler olmadan, öğrenci amatörler düzenlemiştir. Bunlar, tiyatronun isteklerini, belli rollerini, sahnelerini, oyunlarını, sahne biçimlerini öğrenmişler, üslûp bilgisi denemelerini vurgulamışlardır. Terentius, Hans Sachs, Shakespeare gibi çeşitli sahnelerde, açık ve kapalı oyun yerlerinde, çeşitli kavrayışlarla, uyan uymayan roller, düz, dizeli konuşmalar, monologlar, dialoglar denemişlerdir. Bu tiyatro bilimi öğrencilerinde profesyonel oyuncular ya da seyirciler için duyulan kaygılar hiç söz konusu olmamış. Bir deneme başarıldı mı, başı sonu tam olup ilgiyi çekti mi, hemen halka oynanırmış; erekleri yalnızça öğrenmek olduğu halde, gene de sanat yapmak için çaba gösterirlermiş. Sanat uğruna, hiç değilse, meslek tiyatrolarının provalarını görmek, meslekten bir oyuncuyu kendi provalarına çağırıp onun eleştirisini dinlemek için can atarlarmış, Meslekten bir sanatcı olabilmek için de gene öğretim görmeleri gerekli olmuş. Bunun için de iște, hiç değilse, ayda bir öğrenciler, hocalarından ayrı olarak, bu meslekten sanatçıları çağrırlar ve onların pratik çalışmalarından faydalanırlarmış. Bu. öğrencilerin, günün tiyatrolariyle de temas aramaları, büyük sahnelerin provalarını seyretmeleri, bir rejisöre, bütün oyunculariyle bir öğretim provası düzenlendirmeleri, eleştiriden sonra da sahneleri tekrarlattırmaları, hattâ ayni sahneleri, çeşitli oyuncularla, çeşitli kavrayıșla oynatmaları gelenek olmuş.

Bundan da anlaş1ıyor $\mathrm{ki}$, kendisini tiyatroya verecek, tiyatro sorunlariyle uğraşacak adayların artık yurdumuzda da böyle klâsik bir öğretimden geçmeleri zorunlu olmuştur. Yalnız ne var ki, böyle bir öğretimden geçmek, tiyatro konusu üzerinde bilimsel çalışmalarda bulunmak, araştırmalar yapmak isteyen öğrencinin, tiyatroya karşı olan heyecanını ve mimos yeteneğini, az çok beraberinde getirmesi gerekiyor. Bu nitelikler, yalnız sanatçı olacaklar için değil, akademik yolda yürümek isteyenler için de zorunludur. 